\title{
Mesenteric Cystic Lymphangioma: A Case Report
}

\author{
Volkan Kınaş, ${ }^{1}$ Kaptan Gülben, ${ }^{2}$ Uğur Berberoğlu, ${ }^{2}$ Murat Ersen Bekar
}

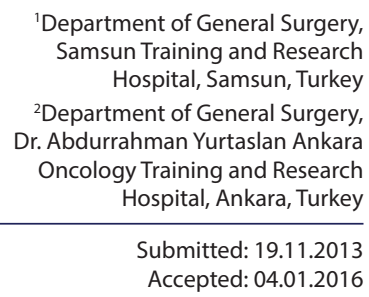

'Department of General Surgery, Samsun Training and Research Hospital, Samsun, Turkey 2Department of General Surgery, Dr. Abdurrahman Yurtaslan Ankara Oncology Training and Research Hospital, Ankara, Turkey

Submitted: 19.11.2013 Accepted: 04.01.2016

Correspondence: Volkan Kınaş, Mimar Sinan Mah., 182. Sk., No: 10 Atakum, Garden Sitesi, B/3, Samsun, Turkey

E-mail:volkankinas@hotmail.com

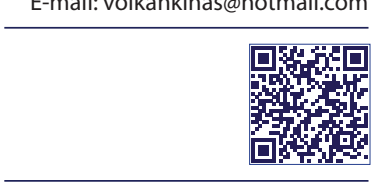

Keywords: Cystic;

lymphangioma; mesentery.

\begin{abstract}
Mesenteric cysts are uncommon intra-abdominal masses that can present with atypical abdominal symptoms. Mesenteric cystic lymphangioma $(\mathrm{MCL})$ is one of the rare forms of mesenteric cysts, and fewer than 200 cases have been reported in the literature. MCLs are benign cystic masses of unknown etiology but have the tendency to recur and invade neighboring structures. The present study reports the case of a 42 -year-old male who underwent the complete resection of an MCL and who was followed up for 8 months postoperatively until determined to be disease free. Moreover, it is an overviewed literature report regarding diagnosis and surgical therapy of disease.
\end{abstract}

\section{INTRODUCTION}

Mesenteric cysts are rare intra-abdominal masses that constitute $1 / 100,000$ of adult hospital admissions and 1/20,000 of child admissions. ${ }^{[1]}$ The clinical behavior of simple lymphatic cysts, lymphangiomas, mesothelial cysts, and benign cystic mesotheliomas are different. Simple lymphatic and mesothelial cysts are usually asymptomatic and stable, while lymphangiomas and benign mesotheliomas may be more aggressive and invasive. Only malignant cystic mesotheliomas are classified as invasive cancer. ${ }^{[2]}$

The mesenteric cyst was first described as a mass during the dissection of an 8-year-old boy by an anatomist in Florence in 1507. ${ }^{[3]}$ The first official description of the lymphatic mesenteric cyst was made by Rockitanski, ${ }^{[4]}$ and the first successful excavation initiative was carried out by Tillaux in $1880 .^{[5]}$

\section{CASE REPORT}

A 42-year-old male patient admitted to the clinic with complaints of swelling and pain in his abdomen, which had been present for about I year. His abdominal pain was moderate, colic, and repeated two or three times a day. No features were found in his personal and family history. The physical examination revealed a painless, palpable mass almost fully filling the paraumbilical region. Whole blood, biochemical values, and tumor markers were completely normal. The lung film and direct abdominal film did not have any features. In the abdominal ultrasonography (USG), a cystic mass lesion $\left(184 \times 186 \times 220 \mathrm{~mm}^{3}\right.$ in size) with a millimetric echogenic stratum was observed in the largest region extending to the left inferior pelvis in the midline of the abdomen. This was followed by double-contrast abdominal computed tomography (CT), which was 


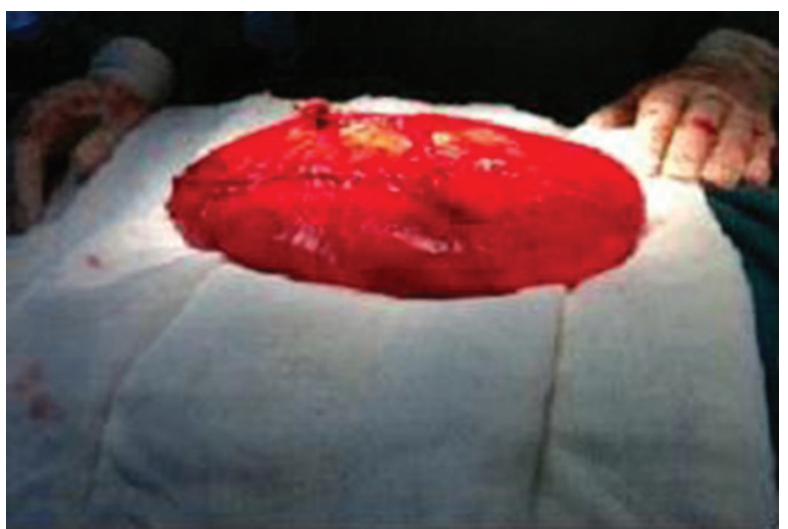

Figure 1. Microscopic appearance of the specimen after excision.

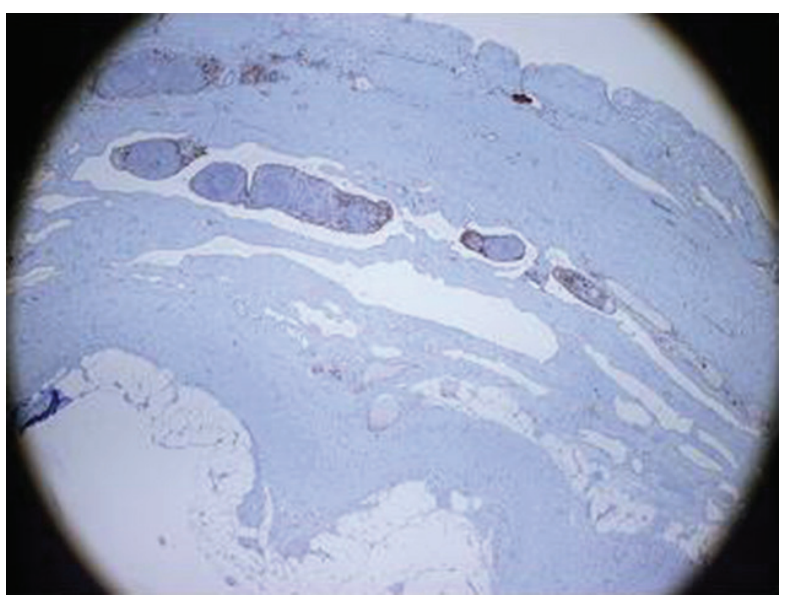

Figure 2. Cystic structures stained with CD31 in immunohistochemical study.

used for a more detailed evaluation of the quality of the lesion, as well as the relation between adjacent structures and mass lesions. The CT revealed a smooth cyst with a smooth edge $\left(211 \times 153 \mathrm{~mm}^{2}\right.$ in size) extending from the epigastric region to the pelvis, pushing the neighboring small and large intestines, and suppressing the left ureter, and in proximity with the vena cava and aorta. No enlarged lymph nodes and acid were observed in the abdomen.

The patient was operated after these findings were reported. At the expulsion, a smooth, cystic mass lesion (approximately $25 \times 20 \times 18 \mathrm{~cm}^{3}$ in size) was observed originating from the small intestine mesentery in the midline of the abdomen. Approximately, $2000 \mathrm{~mL}$ of a clear cyst fluid was aspirated to facilitate surgical manipulation, as the mass to be dissected from the bowel mesentery and surrounding soft tissues was difficult to separate from the mesenteric root adjacent site in the presence of the fluid.
The left ureter during dissection was observed to be attached to the mass wall, and it was injured completely iatrogenically when it was tried to separate (Figure I). The dissection was continued, and the specimen unblock was removed (Figure 2). An end-to-end ureteroureterostomy was performed by placing a stent to the injured left ureteral by the urologist. The ureteral stent was removed on the 10th postoperative day. Two days later, the urine catheter was withdrawn. The patient had no complications following the operation and was discharged on the 15th day. The postoperative pathology report was compatible with mesenteric cystic lymphangioma (MCL). The patient visited both the clinic and urology department and was followed for about 8 months without any problems. Informed consent was taken from the patient.

\section{DISCUSSION}

Mesenteric cystic lymphangiomas (MCL) are congenital malformations that are thought to be the result of a congenital obstruction in the development of primordial lymph nodes. Although it is seen at any age, $50 \%$ of patients are diagnosed at birth while $90 \%$ are diagnosed during the first 2 years of life. ${ }^{[6,7]}$

It is rarely seen in adults. ${ }^{[7,8]}$ Patients admit with nonspecific intestinal findings, such as slowly growing, asymptomatic, fluctuant, soft tissue mass ${ }^{[9]}$ and abdominal distension, as in the present case. ${ }^{[10]}$ Less than $1 \%$ of MCLs originate from the bowel mesentery, retroperitoneum, and large omentum. It originated from the mesentery in the present case. ${ }^{[I]}$ Different theories about the etiology are present, and it is thought to be due to the proliferation and dilatation of the blunt-end lymphatic sacs with no proper connections with venous vessels due to developmental defects in lymphatic vessels. ${ }^{[12]}$

Lymphangiomas are divided into three main types depending on their histological characteristics: capillaries, cavernous, and cystic. The first two types are seen as skin lesions, whereas the cystic type occurs intraabdominally or retroperitoneally. ${ }^{[1]}$ Lymphangiomas consist of cystic areas covered by a single-layered endothelial layer formed by foam cells and have a wall of lymphatic space, lymphatic tissue, and smooth muscle cells. These are also necessary for histological diagnosis. ${ }^{\left[{ }^{[3]}\right.}$ Lymphangiomas are thin-walled cystic lesions of macroscopic cysts (cystic lymphangioma=cystic hygroma) or microscopic cysts (cavernous lymphangioma). 
${ }^{[14]}$ In the present case, the cyst wall had reached $4 \mathrm{~mm}$ in its thickest spot.

Direct abdominal $\mathrm{x}$-ray shows the lateral displacement of the bowel loop. The first method for diagnosis is USG. In abdominal USG, the cyst fluid may be heterogeneous and of high grade due to cellular debris, bleeding, or chylous content. When the cysts are complex, they may suggest hematomas, overcyst torsion, intestinal duplication, or a necrotic tumor. In this case, the computerized tomography is helpful at the differential diagnosis. ${ }^{[10]}$

In MCLs, clinical signs and symptoms may be nonspecific and asymptomatic, and patients may admit with complaints such as chronic or acute abdominal pain, distension, and the presence of a palpable mass. Acute abdominal pain due to intracystic hemorrhage or torsion may be seen, and large cysts may cause partial or complete obstruction by compressing adjacent bowel loops. ${ }^{[10,15]}$ Since lesions often do not cause symptoms due to their small size, they are incidentally detected on radiological examinations. ${ }^{[14]}$

Recently, successful results have been reported with the use of chemical agents such as OK-432, bleomycin, and interferon, for intra-abdominal lymphangiomas, especially the head and neck regions. ${ }^{[16]}$ Aspiration is not a definitive treatment, but it can be used for immediate decompression. The appropriate treatment is complete resection. Segmental intestinal resection may be necessary if the cysts are adherent to the wall. Inadequate surgical resection almost always results in recurrence. ${ }^{[16]}$

In conclusion, although MCLs are seen mostly in the first years of life, they should be considered in patients admitted with mass complaints in advanced age, and it should not be forgotten that the treatment is total excision.
Conflict of interest

None declared.

\section{REFERENCES}

1. Vanek VW, Phillips AK. Retroperitoneal, mesenteric, and omental cysts. Arch Surg 1984;119:838-42.

2. de Perrot M, Bründler M, Tötsch M, Mentha G, Morel P. Mesenteric cysts. Toward less confusion? Dig Surg 2000;17:323-8.

3. Beahrs OH, Judd ES Jr, Dockerty MB. Chylous cysts of the abdomen. Surg Clin North Am 1950;30:1081-96.

4. Kurtz RJ, Heimann TM, Holt J, Beck AR. Mesenteric and retroperitoneal cysts. Ann Surg 1986;203:109-12.

5. Caropreso PR. Mesenteric cysts: a review. Arch Surg 1974;108:2426.

6. Leventi A, Christodoulakis M, Taflapmas P, De Bree E, Melissas J. Mesenteric Cystic Lymphangioma: A case report and literature review. J Surg Radiol 2010;1.

7. Suk S, Sheridan M, Saenger JS. Adult lymphangioma: a case report. Ear Nose Throat J 1997;76:881-3.

8. Morley SE, Ramesar KC, Macleod DA. Cystic hygroma in an adult: a case report. J R Coll Surg Edinb 1999;44:57-8.

9. Alqahtani A, Nguyen LT, Flageole H, Shaw K, Laberge JM. 25 years' experience with lymphangiomas in children. J Pediatr Surg 1999;34:1164-8.

10. Steyaert H, Guitard J, Moscovici J, Juricic M, Vaysse P, Juskiewenski $\mathrm{S}$. Abdominal cystic lymphangioma in children: benign lesions that can have a proliferative course. J Pediatr Surg 1996;31:677-80.

11. Losanoff JE, Richman BW, El-Sherif A, Rider KD, Jones JW. Mesenteric cystic lymphangioma. J Am Coll Surg 2003;196:598-603.

12. Cohen SR, Thompson JW. Lymphangiomas of the larynx in infants and children. A survey of pediatric lymphangioma. Ann Otol Rhinol Laryngol Suppl 1986;127:1-20.

13. Allen JG, Riall TS, Cameron JL, Askin FB, Hruban RH, Campbell KA. Abdominal lymphangiomas in adults. J Gastrointest Surg 2006;10:746-51.

14. Levy AD, Cantisani V, Miettinen M. Abdominal lymphangiomas: imaging features with pathologic correlation. AJR Am J Roentgenol 2004;182:1485-91.

15. Iyer R, Eftekhari F, Varma D, Jaffe N. Cystic retroperitoneal lymphangioma: CT, ultrasound and MR findings. Pediatr Radiol 1993;23:305-6.

16. Weeda VB, Booij KA, Aronson DC. Mesenteric cystic lymphangioma: a congenital and an acquired anomaly? Two cases and a review of the literature. J Pediatr Surg 2008;43:1206-8.

\section{Mezenterik Kistik Lenfanjioma: Olgu Sunumu}

Mezenterik kistler sık karşılaşılmayan karıniçi kitleler olup, atipik karın semptomlarıyla kendini gösterebilir. Mezenterik kistik lenfanjiyom (MKL) mezenterik kistlerin nadir formlarından biridir ve literatürde 200'den daha az olgu bildirilmiştir. Mezenterik kistik lenfanjiyomlar etiyolojisi bilinmeyen benign kistik kitlelerdir, ancak komşu yapıları tutmaya ve nükse eğilim gösterirler. Bu olgu sunumunda, 42 yaşında, tam rezeksiyon uygulanan ve sekiz aydır hastalıksız takip edilen MKL'li bir erkek olgu bildirildi, dahası hastalığın tanısı ve cerrahi tedavisi ile ilgili literatür bilgisi gözden geçirildi.

Anahtar Sözcükler: Kistik; lenfanjiyom; mezenter. 